Jurnal Kesehatan

Volume 11, Nomor 2, Tahun 2020

ISSN 2086-7751 (Print), ISSN 2548-5695 (Online)

http://ejurnal.poltekkes-tjk.ac.id/index.php/JK

\title{
Literature Review: Pemanfaatan Buku Kesehatan Ibu dan Anak (KIA) serta Potensi Pengembangan Selanjutnya
}

\section{Literature Review: Utilization of Maternal and Child Health Books and Potential for Further Development}

\author{
Sugiarti $^{1}$, Yeni Rustina ${ }^{2}$, Defi Efendi ${ }^{3}$ \\ ${ }^{1,2,3}$ Fakultas Ilmu Keperawatan, Universitas Indonesia, Indonesia \\ ${ }^{3}$ Rumah Sakit Universitas Indonesia, Depok, Indonesia
}

\section{ARTICLE INFO}

\section{Article history}

Received date

26 Nov 2019

Revised date

19 Dec 2019

17 July 2020

Accepted date

17 Sept 2020

Keywords:

Child;

Infant;

Maternal and child health handbook;

Mother.

\section{Kata kunci:}

Anak;

Bayi;

Buku Kesehatan Ibu dan

Anak;

Ibu

\author{
ABSTRACT/ ABSTRAK
}

The period of 1000 days of life plays an important role in determining the quality of children's growth and development. Accessibility of quality health services through the $\mathrm{MCH}$ handbook is an important strategy for improving maternal and child health. The purpose of this review is to present an overview of the use and usefulness of the possession of a specific $\mathrm{MCH}$ handbook on maternal, infant and child outcomes, as well as the potential for further research development. The method of systematic study and study search through the ProQuest, EBSCOhost, and Scopus databases, with the keywords maternal and child health handbook, home based record, mother, newborn, infant, and child, published from January 2008 to October 2018. Furthermore, filtering of articles and data abstraction. A total of 56 articles on the use of the $\mathrm{MCH}$ handbook that met the eligibility/inclusion criteria were screened, and 16 articles were selected for a systematic review. The variety of existing studies, has proven the benefits, functions, and effectiveness of the MCH handbook on the health of mothers, infants, and children. The categories of use and use of MCH handbook are integrated with home-based records, namely as an effective tool to facilitate improvement in health-seeking behavior; continuous care; health communication, information and education; as well as home based health records. In order to fill the gap, further research can be directed at evaluating especially premature babies/LBW as part of a population of newborns with high risk. The use of digital technology in improving the implementation of interventions and the accessibility of $\mathrm{MCH}$ handbook is also important to be developed.

Periode 1000 hari kehidupan memegang peranan penting dalam menentukan kualitas pertumbuhan dan perkembangan anak selanjutnya. Aksesibilitas pelayanan kesehatan yang berkualitas melalui buku KIA, merupakan strategi penting untuk meningkatkan kesehatan ibu dan anak. Tujuan review ini untuk menyajikan gambaran pemanfaatan dan kegunaan kepemilikan buku KIA spesifik pada outcome ibu, bayi, dan anak, serta potensi pengembangan penelitian selanjutnya. Metode telaah sistematis dan pencarian studi melalui Database ProQuest, EBSCOhost, dan Scopus, dengan kata kunci maternal and child health handbook, home based record, mother, newborn, infant, dan child yang dipublikasi dari Januari 2008 sampai Oktober 2018. Selanjutnya dilakukan penyaringan artikel dan abstraksi data. Sejumlah 56 artikel tentang pemanfaatan buku KIA yang memenuhi kelayakan/kriteria inklusi disaring, dan 16 artikel terpilih untuk dilakukan tinjauan sistematis. Beragamnya studi yang ada, telah membuktikan manfaat, fungsi, dan efektifitas buku KIA terhadap kesehatan ibu, bayi, dan anak. Kategori pemanfaatan dan kegunaan buku KIA yang terintegrasi dengan catatan berbasis rumah, yaitu sebagai alat yang efektif guna memfasilitasi peningkatan perilaku pencarian kesehatan; perawatan yang berkelanjutan; komunikasi, informasi, dan edukasi kesehatan; serta sebagai rekaman/catatan kesehatan berbasis rumah. Dalam rangka mengisi adanya kesenjangan, penelitian selanjutnya dapat diarahkan pada evaluasi khususnya pada bayi prematur/BBLR sebagai bagian dari populasi bayi baru lahir dengan risiko tinggi. Pemanfaatan teknologi digital dalam meningkatkan implementasi intervensi dan aksesibilitas buku KIA juga dirasakan penting untuk dikembangkan.

\section{Sugiarti}

Fakultas Ilmu Keperawatan, Universitas Indonesia, Indonesia

Email: sugiarti1386@gmail.com 


\section{PENDAHULUAN}

Penurunan Angka Kematian Ibu (AKI) dan Bayi (AKB) tetap menjadi isu penting dalam Sustainable Development Goals (Division SDGs,, 2016). Aksesibilitas pelayanan kesehatan yang berkualitas, baik di komunitas maupun di tingkat rujukan sangat penting untuk mengurangi kematian ibu dan bayi baru lahir (Tobe, Haque, Ikegami, \& Mori, 2018). World Health Organization (WHO) pada tahun 2011 juga menekankan pentingnya intervensi efektif yang berfokus pada pemberian perawatan secara berkesinambungan.

Buku Kesehatan Ibu dan Anak (KIA) telah diperkenalkan dan dikembangkan pada lebih dari 30 negara di dunia, yang merupakan strategi penting dalam rangka meningkatkan kesehatan ibu, bayi baru lahir, dan anak (Akashi, et al., 2018). Sejalan dengan rekomendasi World Health Organization (2018) yakni buku KIA dirancang terintegrasi dengan catatan berbasis rumah/home based record (HBR) (Yanagisawa, et al., 2015; Kaneko, et al., 2017) yang terdiri dari catatan serangkaian perawatan ibu dan anak seperti antenatal care, intranatal care, postnatal care, vaksinasi, pemantauan tumbuh kembang anak, serta terkait kunjungan klinis (Kaneko, et al., 2017).

Periode 1000 hari pertama kehidupan yaitu mulai fese janin (dalam kandungan ibu) dan bayi hingga usia 2 tahun, merupakan periode kritis yang berperan penting dalam perkembangan otak manusia (Chalid, 2014), dan kekurangan gizi pada masa ini juga akan berpengaruh terhadap pertumbuhan anak (Badham \& Sweet, 2010). Khususnya pada bayi yang lahir prematur/BBLR berisiko lebih tinggi untuk mengalami stunting dan selanjutnya akan berdampak terhadap perkembangan kognitif anak (Prendergast and Humprey, 2014). Buku KIA juga berisikan informasi penting guna memastikan kelangsungan perawatan dari sejak masa kehamilan, persalinan, sampai dengan periode membesarkan anak (Ronsmans, et al., 2009; World Health Organization \& UNICEF, 2013). Oleh karena itu, penggunaan buku KIA sebagai salah satu intervensi untuk mengatasi permasalahan tersebut sangatlah diperlukan.

Jepang telah mencapai angka cakupan buku KIA tingkat tinggi, dengan rata-rata cakupan sebesar 100\% (Akashi, et al., 2018; Takeuchi, Sakagami, \& Perez, 2016), namun di beberapa negara lain diketahui bahwa masih terdapat kesenjangan terkait cakupan layanan (Ronsmans, et al., 2009; World Health
Organization \& UNICEF, 2013). Permintaan masyarakat terhadap catatan berbasis rumah juga dapat dikatakan masih rendah (Brown, et al., 2018). Demikian halnya dengan peran petugas kesehatan dan integrasi buku KIA di berbagai program juga belum memadai (World Health Organization, 2015).

Adapun tujuan dari review ini adalah untuk menyajikan gambaran pemanfaatan dan kegunaan kepemilikan buku KIA khususnya pada outcome pengguna layanan ibu, bayi baru lahir, dan anak. Review ini dilakukan berdasarkan studi yang telah ada saat ini, serta untuk mengetahui potensi pengembangan penelitian selanjutnya.

Strategi pencarian secara sistematis didasarkan pada pernyataan Preferred Reporting Items for Systematic Reviews and Meta Analysis (PRISMA) (Liberati, et al., 2009). Artikel ilmiah dipilih melalui database ProQuest, EBSCOhost, dan Scopus. Pencarian dilakukan dengan menggunakan kata kunci: "maternal and child health handbook", "home based record", "mother", "newborn", "infant", dan "child'. Kriteria inklusi studi ini adalah original article yang menilai pemanfaatan dan kegunaan buku KIA/MCH handbook pada ibu, bayi, dan anak; MCHH terintegrasi dengan Home Based Records (HBRs) dipublikasi dari Januari 2008 sampai Oktober 2018; dan berbahasa Inggris. Kriteria eksklusi yaitu artikel review, textbook, letters, editorial, artikel yang membahas tentang pemanfaatan buku kesehatan anak saja atau buku kesehatan maternal saja, artikel lain yang tidak menilai terkait pemanfaatan dan kegunaan buku KIA, serta artikel yang hanya membahas pemanfaatan buku KIA sebagai sumber data sekunder dalam sebuah studi.

Pencarian database awal menghasilkan 316 artikel. Dari jumlah tersebut, sebanyak 28 artikel duplikasi dengan database lainnya. Kemudian dihasilkan 56 abstrak, dan 40 artikel tereliminasi berdasarkan kriteria eksklusi. Adapun alasan dilakukannya eliminasi artikel antara lain: artikel tersebut hanya membahas tentang terkait pemanfaatan buku kesehatan anak saja $(n=2)$, atau tentang buku kesehatan maternal saja $(n=1)$; dalam bentuk literature review $(n=5)$; fokus pembahasan hanya pada fungsi HBR saja $(\mathrm{n}=3)$; membahas pemanfaatan buku KIA hanya sebagai sumber data sekunder dalam suatu studi/ penelitian $(n=23)$; serta artikel lain yang tidak berhubungan dengan pemanfaatan buku KIA sesuai kriteria inklusi $(n=6)$. Selanjutnya sejumlah 16 artikel terpilih untuk dilakukan tinjauan sistematis (Gambar 1). 


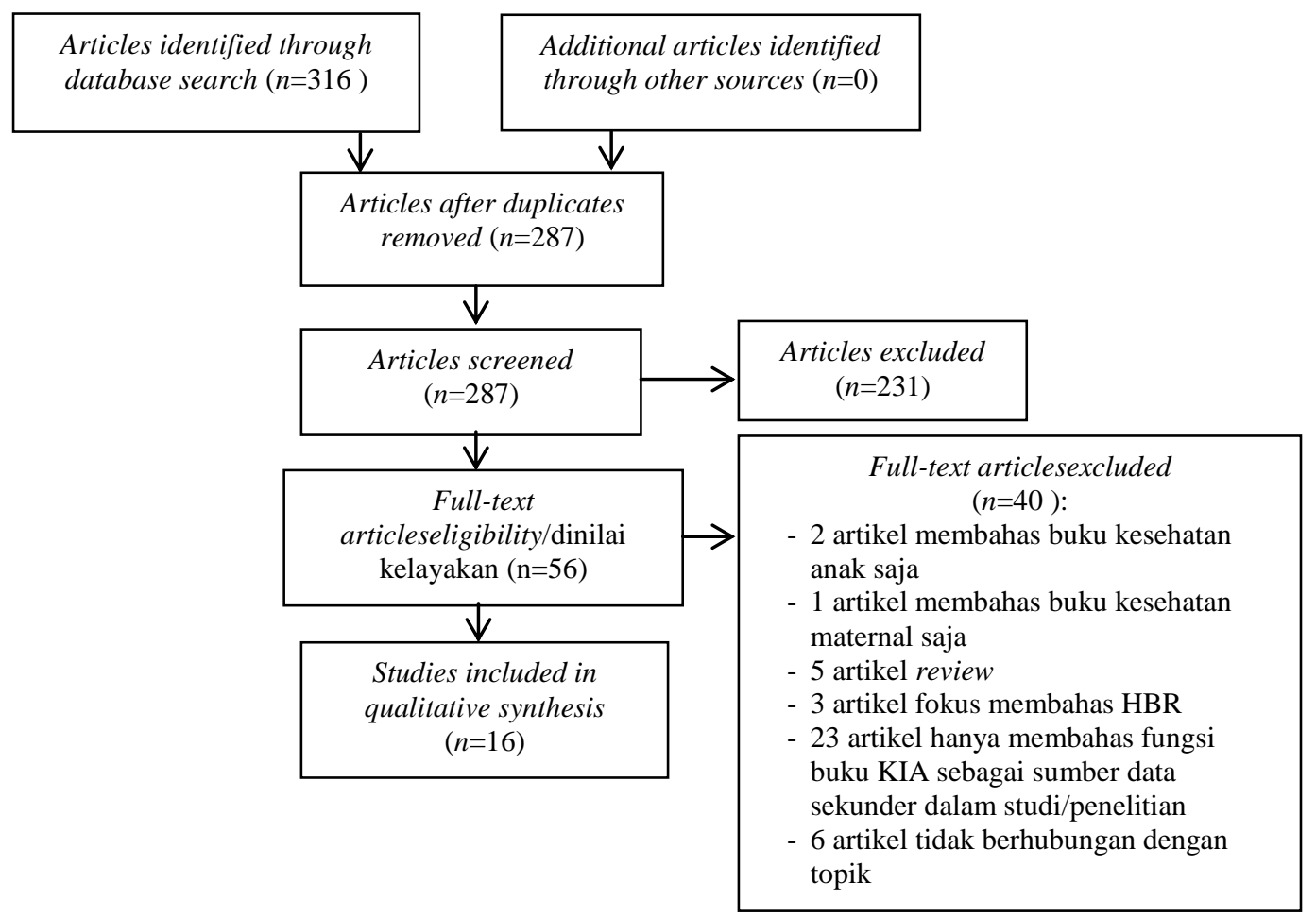

\section{Gambar 1. Pemilihan Artikel sesuai PRISMA}

\section{Karakteristik Studi}

Strategi pencarian menghasilkan 16 studi yang diikutkan dalam review ini, terdiri dari 11 artikel kuantitatif, 1 artikel kualitatif, dan 4 artikel mixed methode. Pemanfaatan buku KIA ditinjau dengan memusatkan pada pengguna layanan yaitu ibu, bayi baru lahir, dan anak. Sebelas studi yang membahas dampak kesehatan pada ibu sebagai pengguna layanan buku KIA, tujuh studi pada pengguna layanan bayi baru lahir dan lima studi pada pengguna layanan anak. Matrix ringkasan dari studi yang dimasukkan dalam telaah (Tabel 1).

\section{Temuan Utama dalam Studi}

Berdasarkan tabel 1, diketahui bahwa buku KIA yang terintegrasi dengan catatan berbasis rumah digunakan dan dimanfaatkan oleh pengguna layanan sebagai alat yang efektif untuk memfasilitasi peningkatan perilaku pencarian kesehatan (health seeking); perawatan yang berkelanjutan (continuum of care) selama kehamilan, persalinan, dan pascapersalinan; komunikasi, informasi, dan edukasi kesehatan (KIE); serta sebagai rekaman/menyimpan catatan kesehatan berbasis rumah.

Tantangan yang dihadapi negara-negara berkembang saat ini yaitu, terkait penyediaan perawatan yang tepat dalam pemberian layanan yang berkelanjutan bagi kesehatan ibu, bayi baru lahir, dan anak (WHO, Aga Khan University, \& Partnership for Reproductive, Maternal, Newborn and Child Health, 2011). Dampak pemanfaatan buku KIA terhadap luaran kesehatan (health outcomes) pada pengguna layanan ibu, bayi baru lahir, dan anak.

\section{Dampak pada Kesehatan Ibu}

Pengaruh buku KIA dalam praktik perawatan kesehatan ibu dalam masa kehamilan maupun setelah persalinan, ditujukan untuk mencapai status kesehatan yang optimal. Bentuk praktik/perilaku perawatan kesehatan tersebut diklasifikasikan dalam tiga periode yakni periode antenatal, intranatal, dan postnatal care. Bentuk praktik/perilaku pada periode antenatal care (ANC) antara lain: melakukan imunisasi tetanus toksoid untuk pencegahan penyakit infeksi sebelum bayi lahir (Osaki, Hattori, Kosen, 2013; Osaki, et al., 2018); suami berpartisipasi lebih baik dalam perawatan kehamilan, dan baik dalam perawatan kehamilan, dan perencanaan kelahiran (Hagiwara, Ueyama, Ramlawi, \& Sawada, 2013); meningkatkan kunjungan perawatan antenatal (Mori, et al., 2015; Yanagisawa, et al., 2015; Osaki, et al., 2018) dengan empat kali atau lebih kunjungan (Aiga, et al., 2016; Kitabayashi, et al., 2017; Tobe, Haque, Ikegami, \& Mori, 2018), 
dan menerima informasi tentang lima atau lebih topik pendidikan kesehatan; menerima tiga jenis pemeriksaan medis (pengukuran tekanan darah, pemeriksaan darah, dan urin) (Kitabayashi, et al., 2017); membantu mengidentifikasi morbiditas ibu selama kehamilan (Mori, et al., 2015); membina komunikasi dua arah dengan profesional kesehatan (McKinn, Duong, Foster, \& McCaffery, 2017); ibu merasa lebih nyaman dan percaya diri ketika hamil, memiliki pengetahuan yang lebih tentang gejala umum, risiko kehamilan dan persalinan, serta tindakan yangharus dilakukan ketika ibu menunjukkan tanda dan gejala risiko tersebut (Hagiwara, Ueyama, Ramlawi, \& Sawada, 2013); mayoritas ibu hamil berhenti minum alkohol, dan menurunnya paparan rokok oleh anggota keluarga selama kehamilan (Mori, et al., 2015); ibu menghindari mengkonsumsi makanan asin, serta untuk tidak bekerja terlalu keras (Yanagisawa, et al., 2015). Pada periode intranatal care (INC) praktik pemanfaatan buku KIA ini ditunjukkan melalui: persalinan ditolong oleh tenaga profesional/terlatih (Yanagisawa, et al., 2015; Osaki, et al., 2018); melahirkan di fasilitas pelayanan kesehatan (Yanagisawa, et al., 2015); menerima dukungan dari suami terkait keuangan, dan menjaga bayi tetap hangat (Osaki, et al., 2018). Sedangkan pada periode postnatal care (PNC), praktik tersebut dalam bentuk: meningkatkan kunjungan PNC (Kaneko, et al., 2017); suami berpartisipasi lebih baik dalam pengasuhan anak (Hagiwara, Ueyama, Ramlawi, Sawada, 2013); dan menerima dukungan suami dalam menstimulasi perkembangan anak (Osaki, et al., 2018).

\section{Dampak pada Kesehatan Bayi Baru Lahir}

Dampak penggunaan buku KIA terhadap kesehatan bayi baru lahir ditunjukkan dalam praktik: melahirkan bayi dengan bantuan tenaga kesehatan terlatih (Osaki, Hattori, Kosen, 2013); inisiasi menyusui dini (IMD) dalam satu jam pertama kelahiran bayi (Mori, et al., 2015; Nasir, Amran, Nakamura, 2017); terus menyusui di rumah (Osaki, et al., 2018); perawatan tali pusat
(Nasir, Amran, \& Nakamura, 2017); praktik pemberian ASI eksklusif (Aiga, et al., 2016); peningkatan pengetahuan tentang pemberian ASI eksklusif sesuai durasi yang direkomendasikan, tanda-tanda bahaya pada bayi baru lahir, dan imunisasi hepatitis pada bayi baru lahir (Nasir, Amran, Nakamura, 2017); peningkatan pengetahuan yang cukup tentang menyusui (Hagiwara, Ueyama, Ramlawi, \& Sawada, 2013); dan tentang pencatatan pemberitahuan kelahiran bayi (Kaneko, et al., 2017).

\section{Dampak pada Kesehatan Anak}

Dampak penggunaan buku KIA terhadap kesehatan anak sebagai dampak penggunaan layanan buku KIA, antara lain: peningkatan pengetahuan ibu tentang kesehatan anak termasuk mengenal tanda bahaya pada anak dan jadwal vaksinasi anak (Kawakatsu, et al., 2015); anak mendapatkan dan memiliki catatan imunisasi lengkap (Osaki, Hattori, Kosen, 2013); catatan tersebut dapat mengurangi peluang kehilangan vaksinasi pada anak (diketahuinya vaksinasi yang sudah diberikan dan mana yang belum); memberikan referensi tanggal kembali untuk vaksinasi selanjutnya; sebagai catatan perawatan dan pemantauan pertumbuhan anak; mengakses layanan perawatan di komunitas maupun klinik; memperoleh akte kelahiran dari pencatatan kelahiran, serta untuk kepentingan masuk sekolah anak (Brown, et al., 2018); meningkatkan kesadaran ibu untuk aktif berinteraksi dengan anak, sehingga membantu menurunkan risiko gangguan perkembangan kognitif pada anak (Dagvadorj, et al., 2017); menerima pemberian suplemen vitamin $\mathrm{A}$; memperkenalkan makanan pendamping ASI, penyediaan pemberian makan yang benar; makan makanan bervariasi; melatih anak makan sendiri, merawat anak batuk, serta memonitor/ mengawasi tingkat overweight dan stunting pada anak (Osaki, et al., 2018); serta mencari pelayanan kesehatan yang baik saat terjadi demam dan diare pada anak (Kawakatsu, et al., 2015). 
Tabel 1. Matrix Ringkasan Studi tentang Pemanfaatan dan Penggunaan Maternal and Child Health Handbook (MCHH)

\begin{tabular}{|c|c|c|c|c|}
\hline $\begin{array}{c}\text { Lokasi } \\
\text { studi }\end{array}$ & Peneliti, tahun & Sampel & Tipe studi & Kategori pemanfaatan buku KIA \\
\hline Bangladesh & $\begin{array}{l}\text { Tobe, et al., } \\
\quad 2018\end{array}$ & 3000 ibu hamil & $\mathrm{RCT}$ & $\begin{array}{l}\text { Meningkatkan perilaku pencarian kesehatan } \\
\text { (health seeking); menjamin perawatan yang } \\
\text { berkelanjutan (continuum } \\
\text { care)selamakehamilan, persalinan, dan pasca } \\
\text { persalinan; memfasilitasi komunikasi, } \\
\text { informasi, dan edukasi kesehatan; dan sebagai } \\
\text { rekaman/catatan kesehatan berbasis rumah. }\end{array}$ \\
\hline \multirow{3}{*}{ Mongolia } & $\begin{array}{l}\text { Dagvadorj, et } \\
\text { al., } 2017\end{array}$ & 386 ibu postpartum & $\mathrm{RCT}$ & \multirow{3}{*}{$\begin{array}{l}\text { Meningkatkan perilaku pencarian kesehatan } \\
\text { (health seeking); menjamin perawatan yang } \\
\text { berkelanjutan (continuum of care)selama } \\
\text { kehamilan, persalinan, dan pasca persalinan; } \\
\text { memfasilitasi komunikasi, informasi, dan } \\
\text { edukasi kesehatan; dan sebagai rekaman/ } \\
\text { catatan kesehatan berbasis rumah. }\end{array}$} \\
\hline & $\begin{array}{l}\text { Mori, et al., } \\
2015\end{array}$ & 458 ibu hamil & $\mathrm{RCT}$ & \\
\hline & $\begin{array}{l}\text { Hikita, et al., } \\
\quad 2018\end{array}$ & $\begin{array}{l}716 \text { ibu dengan anak } \\
\text { berusia } 3 \text { tahun }\end{array}$ & $\begin{array}{l}\text { Cross- } \\
\text { Sectional }\end{array}$ & \\
\hline $\begin{array}{c}\text { Lokasi } \\
\text { studi }\end{array}$ & Peneliti, tahun & Sampel & Tipe studi & Kategori pemanfaatan buku KIA \\
\hline \multirow{4}{*}{ Indonesia } & $\begin{array}{l}\text { Osaki, } \text { et al., } \\
2018\end{array}$ & $\begin{array}{l}454 \text { ibu hamil (follow } \\
\text { up } 2 \text { tahun) }\end{array}$ & $\mathrm{RCT}$ & \multirow{4}{*}{$\begin{array}{l}\text { Meningkatkan perilaku pencarian kesehatan } \\
\text { (health seeking); menjamin perawatan yang } \\
\text { berkelanjutan (continuum of care) selama } \\
\text { kehamilan, persalinan, dan pasca persalinan; } \\
\text { memfasilitasi komunikasi, informasi, dan } \\
\text { edukasi kesehatan. }\end{array}$} \\
\hline & $\begin{array}{l}\text { Nasir, Amran, } \\
\text { \& Nakamura, } \\
2017\end{array}$ & $\begin{array}{l}427 \text { ibu hamil (follow } \\
\text { up sampai periode } \\
\text { bayi baru lahir) }\end{array}$ & $\begin{array}{c}\text { Quasi } \\
\text { eksperimen }\end{array}$ & \\
\hline & $\begin{array}{l}\text { Osaki, Hattori, } \\
\& \text { Kosen, } 2013\end{array}$ & $\begin{array}{c}\text { Analisis data } \\
\text { sekunder (SDKI) }\end{array}$ & $\begin{array}{c}\text { Cross- } \\
\text { Sectional }\end{array}$ & \\
\hline & $\begin{array}{l}\text { Tjandraprawira, } \\
\text { \& Ghozali, } \\
2018\end{array}$ & 127 ibu postpartum & $\begin{array}{l}\text { Cross- } \\
\text { Sectional }\end{array}$ & \\
\hline $\begin{array}{c}\text { Burundi } \\
\text { (Afrika Timur) } \\
\end{array}$ & $\begin{array}{l}\text { Kaneko, et al., } \\
2017 \\
\end{array}$ & $\begin{array}{l}368 \text { Ibu dens } \\
\text { usia < enam }\end{array}$ & $\begin{array}{c}\text { Quasy } \\
\text { eksperiment }\end{array}$ & $\begin{array}{l}\text { Meningkatkan perilaku pencarian kesehatan } \\
\text { (health seeking). }\end{array}$ \\
\hline \multirow[b]{2}{*}{ Kenya } & $\begin{array}{l}\text { Kawakatsu, et } \\
\quad \text { al., } 2015\end{array}$ & $\begin{array}{l}1983 \text { ibu dengan anak } \\
\text { usia 12-24 bulan }\end{array}$ & $\begin{array}{c}\text { Cross- } \\
\text { sectional }\end{array}$ & \multirow{2}{*}{$\begin{array}{l}\text { Meningkatkan perilaku pencarian kesehatan } \\
\text { (health seeking); memfasilitasi komunikasi, } \\
\text { informasi, dan edukasi kesehatan; dan } \\
\text { sebagai rekaman/ catatan kesehatan berbasis } \\
\text { rumah. }\end{array}$} \\
\hline & $\begin{array}{l}\text { Brown, et al., } \\
2018\end{array}$ & $\begin{array}{c}677 \text { anak usia }<24 \\
\text { bulan dan ibu/ } \\
\text { pengasuhnya }\end{array}$ & $\begin{array}{l}\text { Mixed } \\
\text { methods }\end{array}$ & \\
\hline \multirow[t]{2}{*}{ Palestina } & $\begin{array}{l}\text { Hagiwara, } \\
\text { Ueyama, } \\
\text { Ramlawi, \& } \\
\text { Sawada, 2013 }\end{array}$ & $\begin{array}{l}670 \text { ibu hamil (cross } \\
\text { sectional); } 42 \text { ibu dan } \\
25 \text { petugas kesehatan } \\
\text { (FGD) }\end{array}$ & $\begin{array}{l}\text { Mixed } \\
\text { methods }\end{array}$ & \multirow[t]{2}{*}{$\begin{array}{l}\text { Meningkatkan perilaku pencarian kesehatan } \\
\text { (health seeking); memfasilitasi komunikasi, } \\
\text { informasi, dan edukasi kesehatan. }\end{array}$} \\
\hline & $\begin{array}{l}\text { Kitabayashi, et } \\
\text { al., } 2017\end{array}$ & 2026 ibu dan anak & $\begin{array}{c}\text { Cross } \\
\text { sectional }\end{array}$ & \\
\hline Kamboja & $\begin{array}{l}\text { Yanagisawa, et } \\
\text { al., } 2015\end{array}$ & $\begin{array}{l}640 \text { ibu post partum } \\
\text { (Quasy eksperiment); } \\
20 \text { ibu multipara, } 8 \\
\text { staf kesehatan, dan } 10 \\
\text { health volunteers } \\
\end{array}$ & $\begin{array}{l}\text { Mixed } \\
\text { methode }\end{array}$ & $\begin{array}{l}\text { Meningkatkan perilaku pencarian kesehatan } \\
\text { (health seeking). }\end{array}$ \\
\hline \multirow[b]{2}{*}{ Vietnam } & $\begin{array}{l}\text { Aiga, et al., } \\
2016\end{array}$ & $\begin{array}{l}810 \text { ibu dengan anak } \\
\text { usia } 6-18 \text { bulan }\end{array}$ & $\begin{array}{l}\text { Mixed } \\
\text { methode }\end{array}$ & \multirow{2}{*}{$\begin{array}{l}\text { Meningkatkan perilaku pencarian kesehatan } \\
\text { (health seeking); menjamin perawatan yang } \\
\text { berkelanjutan (continuum of care) selama } \\
\text { kehamilan, persalinan, dan pasca persalinan; } \\
\text { memfasilitasi komunikasi, informasi, dan } \\
\text { edukasi kesehatan. }\end{array}$} \\
\hline & $\begin{array}{l}\text { McKinn, } \\
\text { Duong, Foster, } \\
\& \text { McCaffery, } \\
2017\end{array}$ & $\begin{array}{l}37 \text { ibu hamil atau ibu } \\
\text { dari anak balita }\end{array}$ & $\begin{array}{l}\text { Kualitatif } \\
\text { etnografi }\end{array}$ & \\
\hline
\end{tabular}

\section{PEMBAHASAN}

Definisi buku KIA yang dipakai di berbagai negara mengacu pada sumber yang sama berdasakan hasil kerjasama dan pengembangan dengan JICA (Japan International Cooperation Agency). Buku KIA merupakan buku/buklet yang berisi catatan berkelanjutan dari informasi kesehatan dasar berbasis rumah yang digunakan untuk memfasilitasi kesinambungan perawatan secara komperehensif selama kehamilan, persalinan, pascapersalinan, sampai pada periode/tahapan perkembangan anak usia 0-6 tahun (Yanagisawa, et al., 2015; Mori, et al., 2015). Pengembangan isi dari buku KIA juga disesuaikan dengan kondisi dan permasalahan negara pengguna. Seperti salah satu studi di Mongolia yang memandang pentingnya pencatatan kelahiran sebagai dasar pembuatan akte kelahiran, dimana studi ini telah menunjukkan bukti bahwa buku KIA dapat meningkatkan pemberitahuan 
kelahiran melalui fungsi integrasi catatan berbasis rumah, yaitu dengan menambahkan satu halaman khusus untuk pencatatan pemberitahuan kelahiran (Kaneko, et al., 2017).

Mayoritas negara pengguna buku KIA berasal dari negara-negara berkembang, dan pemanfaatannya jarang ditemukan pada negara maju. Jepang merupakan salah satu negara maju yang menggunakan buku KIA, namun saat ini studi di Jepang terkait evaluasi efektifitas pemanfaatanbuku KIA sudah jarang ditemukan. Hal ini dapat dikatakan wajar karena keberhasilan Jepang yang telah mencapai cakupan layanan tingkat tinggi $(100 \%)$ untuk buku KIA (Akashi, et al., 2018; Takeuchi, Sakagami, \& Perez, 2016); sehingga mayoritas studi di Jepang lebih berfokus pada pemanfaatan buku KIA sebagai catatan informasi kesehatan dalam suatu studi/penelitian (sumber data sekunder) (Yokoyama, et al., 2008; Yokoyama, et al., 2009; Tanabe, et al., 2011; Yokoyama, et al., 2011; Kouda, et al., 2012; Yokoyama, et al., 2012; Uno, et al., 2012; Fujita, et al., 2013; Yokoyama, 2013; Mori, et al., 2014; Tanaka \& Miyake, 2014; Ichikawa, Fujiwara, \& Nakayamam, 2015; Hasegawa et al., 2017; Matsuda, et al., 2016; Melby, Yamana, \& Surkan, 2016; Katsuragi, et al., 2017; Kato, et al., 2017; Nanri, et al., 2017; Nishizaki, et al., 2018; Yamakita, et al., 2018). Negara dengan masalah krisis sosial politik, AKI dan AKB yang masih tinggi (Kaneko, et al., 2017), negara berpenghasilan rendah dan menengah (Nakamura, 2010), serta negara dengan keterbatasan sumber daya (Osaki, Hattori, \& Kosen, 2013), sangat disarankan untuk mengimplementasikan buku KIA dan melakukan penelitian lebih lanjut (Mori, et al., 2015). Hasil empiris menunjukkan bahwa catatan dalam bentuk buku KIA ini disambut baik oleh ibu dan layak untuk diterapkan, terutama di negaranegara berpenghasilan rendah (Yanagisawa, et al., 2015). Studi yang dilakukan Dagvadorj, et al. (2017) membuktikan efektifitas buku KIA pada hasil kognitif anak yang lebih baik, sehingga dapat juga membantu memutus mata rantai/siklus kemiskinan.

Intervensi guna memperoleh efektifitas dari pemanfaatan buku KIA dalam tinjauan studi ini meliputi beberapa cara, antara lain edukasi buku KIA melalui "mother class" (Nasir, Amran, Nakamura, 2017); paket intervensi inovatif (kombinasi pesan telepon seluler dan buku KIA) (Tobe, et al., 2018); menerima buku KIA, layanan, panduan serta catatan sesuai buku KIA (Yanagisawa, et al., 2015; Kaneko, et al., 2017; Dagvadorj, et al., 2017; Mori, et al., 2015;
Hikita, et al., 2018; Osaki, et al., 2018; Tjandraprawira \& Ghozali, 2018; Kawakatsu, et al., 2015; Hagiwara, Ueyama, Ramlawi, \& Sawada, 2013; Kitabayashi, et al., 2017; Aiga, et al., 2016; Osaki, Hattori, \& Kosen, 2013); dan melibatkan sukarelawan dalam melakukan kunjungan rumah (Osaki, et al., 2018). Terkait penyampaian informasi dalam buku KIA, diketahui bahwa mayoritas tenaga kesehatan memberikan informasi kesehatan (berkomunikasi) dengan gaya didaktik, satu arah, dan ketergantungan terhadap informasi yang tertulis pada buku KIA (McKinn, Duong, Foster, McCaffery, 2017). Untuk meningkatkan efektifitas penggunaan buku KIA, direkomendasikan agar tenaga medis menerima pelatihan, sehingga mereka dapat menjelaskan isi dan tujuan buku KIA dengan lebih jelas (Nakamura, 2010). Guna meningkatkan komunikasi antara profesional kesehatan dan pengguna layanan, pelatihan tentang komunikasi juga dapat dimasukkan bersamaan dengan penerapan informasi tertulis (McKinn, Duong, Foster, McCaffery, 2017).

Kualitas metodologi penelitian dalam studi yang menilai pemanfaatan buku KIA ini masih ditemukan banyak keterbatasan, walaupun beberapa studi telah menggunakan desain RCT (Mori, et al., 2015; Dagvadorj, et al., 2017; Osaki, et al., 2018; Tobe, Haque, Ikegami, \& Mori, 2018). Keterbatasan tersebut antara lain terkait bias penelitian yaitu: sampel yang kurang representatif oleh karena follow up dalam jangka waktu yang lama sehingga potensial dropout; bias analisis; tidak dapat dilakukannya masking pada pengacakan, intervensi, dan hasil; serta terkait desain penelitian lainnya misalnya pada studi cross sectional atau kualitatif dengan risiko bias data, karena mengandalkan laporan/ ingatan peserta; serta bias respon oleh karena pewawancara dan peserta saling mengenal. Penelitian selanjutnya, perlu meningkatkan penerapan metode penelitian yang lebih baik lagi, dengan meminimalkan potensi bias. Penggunaan teknologi informasi terkini, seperti aplikasi smartphone terhadap pemanfaatan buku KIA (Tobe, Haque, Ikegami, \& Mori, 2018), juga dapat memberikan kesempatan berharga untuk dapat meningkatkan aksesibilitas Buku KIA, dan memperoleh manfaat lebih lanjut dari penelitian (Mori, et al., 2015). Pemutakhiran teknologi saat ini juga seharusnya dapat menjadi alternatif pertimbangan untuk memanfaatkan teknologi dalam meningkatkan kuantitas dan kualitas dari pencapaian cakupan buku KIA.

Dampak buku KIA terhadap pengetahuan ibu pada masa kehamilan sangat beragam. Studi 
di Palestina memberi bukti tentang efektivitas buku KIA dalam meningkatkan pengetahuan ibu terkait dengan praktik menyusui dan bagaimana mengatasi risiko ketuban pecah dini, tetapi penelitian tidak berfokus pada tanda-tanda bahaya lainnya (Hagiwara, Ueyama, Ramlawi, \& Sawada, 2013). Efektifitas buku KIA dalam meningkatkan pengetahuan tentang perawatan antenatal juga diketahui masih bersifat komplementer atau terbatas (Aiga, et al., 2016). Sedangkan studi yang dilakukan Tjandraprawira dan Ghozali (Tjandraprawira, \& Ghozali, 2018) di Indonesia menyimpulkan bahwa populasi dalam penelitian telah menunjukkan pengetahuan yang tinggi, dan buku KIA tidak menunjukkan bukti yang signifikan dalam memengaruhi peningkatkan tingkat pengetahuan ibu tentang kehamilan dan tanda bahaya kehamilan. Namun penelitian tersebut juga belum sampai mengevaluasi pengetahuan ibu terkait praktik perawatan/pengasuhan pada bayi baru lahir dan anak. Variasi hasil dalam penilaian luaran pengetahuan ini mungkin selain karena perbedaan dalam metodologi penelitian, juga karena karakteristik demografi dan populasi penelitian antara satu negara dengan negara lainnya yang berbeda. Tingkat literasi perempuan, pencapaian pendidikan, status ekonomi dan penjelasan yang efektif tentang penggunaan, harus dipertimbangkan untuk meningkatkan efektivitas buku KIA (Hikita, et al., 2018). Pengguna buku KIA mungkin juga tidak terbiasa menggunakannya, meskipun mereka mungkin telah menerima penjelasan dari petugas kesehatan (Hikita, et al., 2018).

Pendekatan penggunaan buku KIA yang tepat tidak hanya dilakukan pada tahap kehamilan saja, tetapi juga sampai pada tahap pengasuhan awal yakni diseluruh rangkaian program perawatan bayi dan anak. Pada tahun 2016, secara global prevalensi stunting pada balita di dunia adalah sebesar 22,9\% (UNICEF, WHO, \& World Bank Group, 2017). Studi Beal, et al. (2018) menyatakan bahwa faktor penentu utama terjadinya stunting pada anak di Indonesia antara lain karena adanya hambatan pemberian ASI eksklusif selama 6 bulan pertama, kelahiran prematur, rendahnya status sosial ekonomi keluarga, panjang lahir pendek, dan juga faktor ibu (bertubuh pendek, serta berpendidikan rendah). Menurut Prendergast dan Humprey (2014) stunting pada anak yang berusia kurang dari 2 tahun ini masih bersifat responsif, atau dapat dicegah dengan intervensi. Namun demikian, integrasi buku KIA dengan program perawatan pada populasi bayi dengan risiko tinggi masih dirasakan belum optimal, sebagai contoh dalam konten materi buku KIA versi Indonesia belum memuat tentang perawatan spesifik pada bayi prematur dan/atau bayi berat lahir rendah (BBLR).

Eksplorasi lebih lanjut terkait faktor-faktor gizi pada anak juga sangat diperlukan. Kasuskasus kurang gizi yang kurang terperhatikan seperti wasting dan stunting yang sering dijumpai saat ini, selanjutnya mendorong penggunaan buku KIA untuk dapat menjanjikan perawatan yang baik pada 1000 hari pertama kehidupan anak (Dagvadorj, et al., 2017). Data berat badan lahir yang dicatat dalam buku KIA juga penting untuk akurasi pemantauan terhadap pertumbuhan anak, termasuk terkait kejadian stunting (Kaneko, et al., 2017). Oleh karena itu, penelitian yang berkualitas untuk menilai efektivitas buku KIA guna memfasilitasi pemberian informasi jangka panjang terhadap pertumbuhan dan perkembangan anak juga perlu dilakukan (Mori, et al., 2015; Dagvadorj, et al., 2017; Osaki, et al., 2018).

Dari beberapa studi yang ada, penelitian yang mengevaluasi kegunaan buku KIA pada perkembangan bayi baru lahir, khususnya pada bayi prematur/ BBLR masih belum ditemukan. Kelahiran prematur dan Intrauterine Growth Restriction (IUGR) merupakan etiologi dari BBLR, dimana keduanya terkait secara kausal terhadap morbiditas dan mortalitas pada periode perinatal dan bayi (Hughes, Black, \& Katz, 2017). Sementara itu, saat ini tantangan baru kebijakan perawatan kesehatan tidak hanya berfokus pada menurunkan angka kematian, tetapi juga menargetkan pada pencegahan penyakit kronis, peningkatan kualitas hidup, dan perkembangan anak (Takehara, et al., 2016). Untuk meningkatkan keefektifan pemanfaatan buku KIA, direkomendasikan juga kepada petugas kesehatan untuk dapat memberikan perhatian secara khusus pada ibu yang lebih muda/paritas rendah (Kaneko, et al., 2017). Ibu muda yang memiliki bayi prematur/ BBLR juga dikaitkan dengan kepercayaan diri yang rendah dalam merawat bayinya, hal ini kemungkinan dikarenakan kurangnya pengetahuan, pengalaman, dan kemampuan dalam merawat bayi (Kenanga, Rustina, \& Budiati, 2017).

Keterbatasan dalam tinjauan ini antara lain yaitu beragamnya jenis studi, baik penelitian kualitatif maupun kuantitatif yang diikutsertakan dalam telaah. Oleh karena itu, studi ini masih belum dapat menggambarkan hasil dengan data ukuran yang spesifik, ataupun melakukan analisis literatur secara statistik. 


\section{SIMPULAN}

Banyak dan beragamnya studi yang ada telah menunjukkan efektivitas buku KIA pada kesehatan ibu, bayi, dan anak, yakni terkait pengembangan beberapa setting layanan perawatan kesehatan. Pemanfaatan dan kegunaan buku KIA yang terintegrasi dengan catatan berbasis rumah ini antara lain sebagai alat yang efektif untuk memfasilitasi: peningkatan perilaku kesehatan (health seeking); perawatan yang berkelanjutan (continuum of care) selama periode antenatal, intranatal, dan postnatal; komunikasi, informasi, dan edukasi kesehatan; serta sebagai

\section{DAFTAR PUSTAKA}

Aiga, H., Nguyen, V. D., Nguyen, C. D., Nguyen, T. T. T., \& Nguyen, L. T. P. (2016). Knowledge, attitude and practices: Assessing Maternal and Child Health Care Handbook intervention in Vietnam. BMC Public Health, 16(1), 1-10. https://doi.org/10.1186/s12889-016-2788-4

Akashi, H., Ishioka, M., Hagiwara, A., Akashi, R., \& Osanai, Y. (2018). Core factors promoting a continuum of care for maternal, newborn, and child health in Japan.BioScience Trends, 12(1), 1-6. https://doi.org/10.5582/bst.2017.01304

Badham, J., \& Sweet, L. (2010). Stunting: An overview. Sight and Life Magazine. 3, 40-47. https://sightandlife.org/wp-

content/uploads/2017/04/Sight-and-LifeMagazine-03-2010.pdf

Beal, T., Tumilowicz, A., Sutrisna, A., Izwardy, D., \& Neufeld, L. M. (2018). A review of child stunting determinants in Indonesia.Maternal \& Child Nutrition, (March), e12617, 1-10. https://doi.org/10.1111/mcn.12617

Brown, D. W., Tabu, C., Sergon, K., Shendale, S., Mugoya, I., Machekanyanga, Z., ... Ogbuanu, I. U. (2018). Home-based record (HBR) ownership and use of HBR recording fields in selected Kenyan communities: Results from the Kenya Missed Opportunities for Vaccination Assessment. PLoS ONE, 13(8), 1-14. https://doi.org/10.1371/journal.pone.0201538

Brown, H. C., Smith, H. J., Mori, R., \& Noma, H. (2015). Giving women their own case notes to carry during pregnancy. Cochrane Database of Systematic Reviews. rekaman/menyimpan catatan kesehatan berbasis rumah.

Studi lain yang masih belum banyak ditemukan yaitu terkait evaluasi pemanfaatan buku KIA yang spesifik membahas kesehatan dan perawatan pada bayi prematur/BBLR sebagai bagian dari populasi bayi baru lahir dengan risiko tinggi. Selain itu, memanfaatkan teknologi digital sebagai teknologi informasi terkini juga penting dikembangkan untuk meningkatkan implementasi intervensi dan aksesibilitas dari buku KIA. Dalam rangka meningkatkan efektifitas kualitas studi selanjutnya, perlu dipertimbangkan penggunaan metode untuk meminimalkan ragam potensi bias yang mungkin terjadi.

https://doi.org/10.1002/14651858.CD0028 56.pub3

Chalid, M.T. (2014). Gambaran umum program 1000 hari awal kehidupan. Research Gate. https://www.researchgate.net/publication/3 01895562

Dagvadorj, A., Nakayama, T., Inoue, E., Sumya, N., \& Mori, R. (2017). Cluster randomised controlled trial showed that maternal and child health handbook was effective for child cognitive development in Mongolia. Acta Paediatrica, International Journal of Paediatrics, 106(8), 1360-1361. https://doi.org/10.1111/apa.13864

Division Sustainable Development Goals. (2016). Goal 3: Ensure healthy lives and promote well-being for all at all ages. New York: UNDESA.

https://www.un.org/sustainabledevelopmen t/health/

Fujita, Y., Kouda, K., Nakamura, H., \& Iki, M. (2013).Association of rapid weight gain during early childhood with cardiovascular risk factors in Japanese adolescents. Journal of Epidemiology, 23(2), 103-108. https://doi.org/10.2188/jea.JE20120107

Hagiwara, A., Ueyama, M., Ramlawi, A., \& Sawada, Y. (2013). Is the Maternal and Child Health $(\mathrm{MCH})$ handbook effective in improving health-related behavior Evidence from Palestine. Journal of Public Health Policy, 34(1), 31-45. https://doi.org/10.1057/jphp.2012.56

Hasegawa, J., Mori, M., Ohnishi, H., Tsugawa, T., Hori, T., Yoto, Y., \& Tsutsumi, H. (2017). Pneumococcal vaccination reduces the risk of community-acquired pneumonia in children. Pediatrics International, 59(3), 
316-320.

https://doi.org/10.1111/ped.13157

Hikita, N., Haruna, M., Matsuzaki, M., Shiraishi, M., Takehara, K., Dagvadorj, A., ... Mori, R. (2018). Utilisation of Maternal and Child Health Handbook in Mongolia: A cross-sectional study. Health Education Journal, 77(4), 458-469. https://doi.org/10.1177/0017896917753649

Hughes, M. M., Black, R. E., \& Katz, J. (2017). 2500-g low birth weight cutoff: History and implications for future research and policy. Maternal and Child Health Journal, 21(2), 283-289. https://doi.org/10.1007/s10995-016-2131-9

Ichikawa, K., Fujiwara, T., \& Nakayama, T. (2015). Effectiveness of home visits in pregnancy as a public health measure to improve birth outcomes. PLoS ONE, 10(9), $1-13$.

https://doi.org/10.1371/journal.pone.0137307

Kaneko, K., Niyonkuru, J., Juma, N., Mbonabuca, T., Osaki, K., \& Aoyama, A. (2017).Effectiveness of the Maternal and Child Health handbook in Burundi for increasing notification of birth at health facilities and postnatal care uptake. Global Health Action, 10(1).

https://doi.org/10.1080/16549716.2017.12 97604

Katsuragi, S., Okamura, T., Kokubo, Y., Ikeda, T., \& Miyamoto, Y. (2017).Birthweight and cardiovascular risk factors in a Japanese general population.Journal of Obstetrics and Gynaecology Research, 43(6), 1001-1007. https://doi.org/10.1111/jog.13316

Kato, H., Tanaka, K., Shimizu, K., Nagata, C., Furukawa, S., Arakawa, M., \& Miyake, Y. (2017). Parental occupations, educational levels, and income and prevalence of dental caries in 3-year-old Japanese children. Environmental Health and Preventive Medicine, 22(1), 1-7. https://doi.org/10.1186/s12199-017-0688-6

Kawakatsu, Y., Sugishita, T., Oruenjo, K., Wakhule, S., Kibosia, K., Were, E., \& Honda, S. (2015). Effectiveness of and factors related to possession of a mother and child health handbook: An analysis using propensity score matching. Health Education Research, 30(6), 935-946. https://doi.org/10.1093/her/cyv048

Kenanga, P., E., Rustina, Y., \& Budiarti, T. (2017). Increasing confidence and ability in implementing kangaroo mother care method among young
mothers.Comprehensive Child and Adolescent Nursing, 40(1), 1-7. https://doi.org/10.1080/24694193.2017.13 86964

Kitabayashi, H., Chiang, C., Al-Shoaibi, A. A. A., Hirakawa, Y., \& Aoyama, A. (2017). Association between Maternal and Child Health Handbook and quality of antenatal care services in Palestine. Maternal and Child Health Journal, 21(12), 2161-2168. https://doi.org/10.1007/s10995-017-2332-x

Kouda, K., Nakamura, H., Fujita, Y., \& Iki, M. (2012). Relationship between body mass index at age 3 years and body composition at age 11 years among Japanese children: The Shizuoka Population-Based Study. Journal of Epidemiology, 22(5), 411-416. https://doi.org/10.2188/jea.JE20110113

Liberati, A., Altman, D. G., Tetzlaff, J., Mulrow, C., Gøtzsche, P. C., Ioannidis, J. P. A., ... Moher, D. (2009). The PRISMA statement for reporting systematic reviews and metaanalyses of studies that evaluate health care interventions: explanation and elaboration. Journal of Clinical Epidemiology, 62(10), e134.https://doi.org/10.1016/j.jclinepi.2009.0 6.006

Matsuda, Y., Manaka, T., Kobayashi, M., Sato, S., \& Ohwada, M. (2016). Exploratory analysis of textual data from the Mother and Child Handbook using the text-mining method: Relationships with maternal traits and post-partum depression. Journal of Obstetrics and Gynaecology Research, 42(6), 655-660. https://doi.org/10.1111/jog.12971

McKinn, S., Duong, L. T., Foster, K., \& McCaffery, K. (2017). "I do want to ask, but i can't speak": A qualitative study of ethnic minority women's experiences of communicating with primary health care professionals in remote, rural Vietnam. International Journal for Equity in Health, 16(1), 1-12.

https://doi.org/10.1186/s12939-017-0687-7

Melby, M. K., Yamada, G., \& Surkan, P. J. (2016). Inadequate gestational weight gain increases risk of small-for-gestational-age term birth in girls in Japan: A populationbased cohort study. American Journal of Human Biology: The Official Journal of the Human Biology Council, 28(5), 714720. https://doi.org/10.1002/ajhb.22855

Mori, M., Hasegawa, J., Showa, S., Matsushima, A., Ohnishi, H., Yoto, Y., \& Tsutsumi, H. (2014). Effectiveness of influenza vaccine 
in children in day-care centers of Sapporo. Pediatrics International, 56(1), 53-56. https://doi.org/10.1111/ped.12221

Mori, R., Yonemoto, N., Noma, H., Ochirbat, T., Barber, E., Soyolgerel, G., ... Lkhagvasuren, O. (2015). The Maternal and Child Health (MCH) handbook in Mongolia: A cluster-randomized, controlled trial. PLOS ONE, 10(4), 1-12. https://doi.org/10.1371/journal.pone.01197 72

Nakamura, Y. (2010). Maternal and child health handbook in Japan.Japan Medical Association Journal, 53(4), 259-265. Retrieved November 24, 2018, from https://www.med.or.jp/english/journal/pdf/ 2010_04/259_265.pdf

Nanri, H., Shirasawa, T., Ochiai, H., Nomoto, S., Hoshino, H., \& Kokaze, A. (2017). Rapid weight gain during infancy and early childhood is related to higher anthropometric measurements in preadolescence. Child: Care, Health and Development, 43(3), 435-440. https://doi.org/10.1111/cch.12455

Nasir, N. M., Amran, Y., \& Nakamura, Y. (2017).Changing knowledge and practices of mothers on newborn care through mother class: An intervention study in Indonesia.Journal of Tropical Pediatrics, 63(6), 440-446.

https://doi.org/10.1093/tropej/fmx010

Nishizaki, N., Obinata, K., Kantake, M., Yoshida, N., Ohtomo, Y., Niijima, S., ... Shimizu, T. (2018). Association between the frequency of bedwetting and late preterm birth in children aged $\geq 5$ years. Acta Paediatrica, International Journal of Paediatrics, 108(2), 282-287. https://doi.org/10.1111/apa.14481

Osaki, K., Hattori, T., \& Kosen, S. (2013).The role of home-based records in the establishment of a continuum of care for mothers, newborns, and children in Indonesia. Global Health Action, 6(1).https://doi.org/10.3402/gha.v6i0.20429

Osaki, K., Hattori, T., Toda, A., Mulati, E., Hermawan, L., Pritasari, K., ... Kosen, S. (2018). Maternal and Child Health Handbook use for maternal and child care: a cluster randomized controlled study in rural Java, Indonesia. Journal of Public Health, (February), 1-13. https://doi.org/10.1093/pubmed/fdx175

Prendergast, A. J., \& Humphrey, J. H. (2014). The stunting syndrome in developing countries.Paediatrics and International
Child Health, 34(4), 250-265. https://doi.org/10.1179/2046905514Y.000 0000158

Ronsmans, C., Scott, S., Qomariyah, S. N., Achadi, E., Braunholtz, D., Marshall, T., ... Graham, W. J. (2009). Professional assistance during birth and maternal mortality in two Indonesian districts.Bulletin of the World Health Organization, 87(6), 416-423. https://doi.org/10.2471/BLT.08.051581

Takehara, K., Dagvadorj, A., Hikita, N., \& Sumya, N. (2016). Maternal and child health in Mongolia at 3 years after childbirth: A population based cross sectional descriptive study. Maternal and Child Health Journal, 20(5), 1072-1081. https://doi.org/10.1007/s10995-015-1893-9

Takeuchi, J., Sakagami, Y., \& Perez, R. C. (2016). The mother and child health handbook in Japan as a health promotion tool: An overview of its history, contents, use, benefits, and global influence. Global Pediatric Health, 3,1-9. https://doi.org/10.1177/2333794X16649884

Tanabe, K., Tamakoshi, K., \& Murotsuki, J. (2011).Association of women's birth weight with their blood pressure during pregnancy and with the body size of their babies.The Tohoku Journal of Experimental Medicine, 224(4), 287-292. https://doi.org/10.1620/tjem.224.287

Tanaka, K., \& Miyake, Y. (2014). Low birth weight, preterm birth or small for gestational age are not associated with dental caries in young Japanese children. BMC Oral Health, 14(1), 38. https://doi.org/10.1186/1472-6831-14-38

Tjandraprawira, K. D., \& Ghozali, I. (2018). Knowledge of pregnancy and its danger signs not improved by maternal and child health handbook.The Journal of Obstetrics and Gynecology of India. https://doi.org/10.1007/s13224-018-1162-0

Tobe, R. G., Haque, S. E., Ikegami, K., \& Mori, R. (2018). Mobile-health tool to improve maternal and neonatal health care in Bangladesh: a cluster randomized controlled trial. BMC Pregnancy and Childbirth, 18(1), 102. https://doi.org/10.1186/s12884-018-1714-4

UNICEF, WHO, World Bank Group. (2017). Levels and trends in child malnutrition. UNICEF/WHO/World Bank Group joint child malnutrition estimates. Geneva: United Nations Children's Fund, World Health Organization, World Bank Group. 
Retrieved October 2, 2018, from http://www.who.int/nutgrowthdb/jmebroch oure2017.pdf?ua $=1$

Uno, Y., Uchiyama, T., Kurosawa, M., Aleksic, B., \& Ozaki, N. (2012). The combined measles, mumps, and rubella vaccines and the total number of vaccines are not associated with development of autism spectrum disorder: The first case-control study in Asia. Vaccine, 30(28), 4292-4298. https://doi.org/10.1016/j.vaccine.2012.01.093

World Health Organization.(2015). Practical guide for the design, use and promotion of home-based records in immunization programmes.Geneva: World Health Organization.

www.who.int/immunization/documents

World Health Organization, Aga Khan University, \& Partnership for Maternal and Child Health. (2011). Essential interventions, commodities and guidelines for reproductive, maternal, newborn and child health: A global review of the key interventions related to reproductive, maternal, newborn and child health. Geneva: Switzerland.

https://www.who.int/pmnch/topics/part_pu blications/essential_interventions_18_01_2 012.pdf

World Health Organization \& UNICEF. (2013). Accountability for maternal, newborn \& child survival: The 2013 update. Geneva: World Health Organization and UNICEF. Retrieved November 22, 2018, from https://www.who.int/woman_child_accoun tability/ierg/reports/Countdown_Accounta bility_2013Report.pdf

World Health Organization. (2018). WHO recommendations on home-based records for maternal, newborn and child health. Geneva: World Health Organization. http://www.who.int/immunization/monitorin gsurveillance/routine/homebasedrecords/en/

Yamakita, M., Sato, M., Suzuki, K., Ando, D., \& Yamagata, Z. (2018). Sex differences in birth weight and physical activity in Japanese schoolchildren. Journal of Epidemiology, 28(7), 331-335. https://doi.org/10.2188/jea.JE20170078

Yanagisawa, S., Soyano, A., Igarashi, H., Ura, M., \& Nakamura, Y. (2015). Effect of a maternal and child health handbook on maternal knowledge and behaviour: A community-based controlled trial in rural Cambodia. Health Policy and Planning, 30(9), 1184-1192. https://doi.org/10.1093/heapol/czu133

Yokoyama, Y., Sugimoto, M., Pitkäniemi, J., Kaprio, J., \& Silventoinen, K. (2011). Height growth of triplets from birth to 12 Years of Age in Japan. Twin Research and Human Genetics, 14(5), 468-475. https://doi.org/10.1375/twin.14.5.468

Yokoyama, Y., Sugimoto, M., Silventoinen, K., \& Kaprio, J. (2008). Weight growth charts from birth to 6 years of age in Japanese triplets. Twin Research and Human Genetics, 11(6), 641-647. https://doi.org/10.1375/twin.11.6.641

Yokoyama, Y., Sugimoto, M., Silventoinen, K., Pitkäniemi, J., \& Kaprio, J. (2009). Growth charts of length and height from birth to six years of age in Japanese triplets. Twin Research and Human Genetics, 12(03), 320-327. doi:10.1375/twin.12.3.320

Yokoyama, Y., Pitkäniemi, J., Kaprio, J., \& Silventoinen, K. (2013).Development of body mass index of Japanese triplets from birth until the onset of puberty.Twin Research and Human Genetics, 16(4), 861-868.

https://doi.org/10.1017/thg.2013.39

Yokoyama, Y., Pitkäniemi, J., Kaprio, J., \& Silventoinen, K. (2012).Weight growth of triplet infants from birth to twelve years of age.Twin Research and Human Genetics, 15(5), 672-679.

https://doi.org/10.1017/thg.2012.42 